\title{
Raspberry and Strawberry Addition Improves Probiotic Viability in Yogurt and Possess Antioxidant Activity
}

\author{
Aynur Gunenc ${ }^{1}$, Susanna Fang ${ }^{1} \&$ Farah Hosseinian ${ }^{1,2}$ \\ ${ }^{1}$ Food Science and Nutrition Division of Chemistry Department, Carleton University, Ottawa, Ontario, Canada \\ ${ }^{2}$ Institute of Biochemistry, Carleton University, Ottawa, Ontario, Canada \\ Correspondence: Farah Hosseinian, Food Science and Nutrition Division of Chemistry Department, Carleton \\ University, Ottawa, Ontario, K1S5B6, Canada. Tel: 1-613-520-2600 ext 2048. E-mail: \\ farah_hosseinian@carleton.ca
}

Received: April 17, 2015 Accepted: May 12, 2015 Online Published: May 13, 2015

doi:10.5539/jfr.v4n4p47 URL: http://dx.doi.org/10.5539/jfr.v4n4p47

\begin{abstract}
This study aimed to i) investigate probiotic potentials of raspberry and strawberry addition in yogurts, ii) explore antioxidant activity of berries extracted by microwave using oxygen radical absorbance (ORAC), and 2,2-diphenyl-1-picryhydrazyl radical (DPPH) as well as iii) determine the total phenolic content (TPC) of the berries. The probiotic potentials of those berry additions into yogurts containing different probiotics were determined by subsequent viable microorganism counts in each yogurt trial using selective media, $\mathrm{pH}$ and total titratable acidity (TTA) during 28 days of cold storage at $4^{\circ} \mathrm{C}$. Viable microbial counts in yogurt trials containing probiotic Lactobacillus acidophilus and raspberry increased $(\mathrm{P}<0.05)$ for 21 consecutive days of cold storage. The pH levels decreased $(\mathrm{P}<0.05)$ as the TTA increased over 28 days of cold storage in all yogurts containing the berries. ORAC results showed that raspberry had higher antioxidant activity $(505.72 \mu \mathrm{mol} \mathrm{TE} / 100 \mathrm{~g}$ of fruit) than strawberry $(495 \mu \mathrm{mol} \mathrm{TE} / 100 \mathrm{~g}$ of fruit). Also, DPPH scavenging activity results showed that raspberry $(86.11 \%)$ had higher antioxidant activity than strawberry $(85.69 \%)$. There was not a significant $(\mathrm{P}<0.05)$ difference in TPC values of raspberry $(0.20 \mathrm{~g} \mathrm{GAE} / \mathrm{kg})$ and strawberry $(0.18 \mathrm{~g} \mathrm{GAE} / \mathrm{kg})$. This study suggests that both berries have potential as a source of prebiotics with antioxidant activity for future functional foods and nutraceutical applications.
\end{abstract}

Keywords: microwave extraction, probiotic, raspberry, selective media, strawberry, ORAC, yogurt

\section{Introduction}

Berries like strawberry (Fragaria $\times$ ananassa Duch.) and raspberry (Rubus idaeus L.) are traditionally known as part of Nordic diet (Willett et al., 1995). They are an important source of fiber and bioactive compounds like polyphenolics and well recognized because of their positive health effects on human health, especially in the prevention of various oxidative stress associated diseases like cancer (Del Rio et al., 2013).

Prebiotics are nondigestible food carbohydrates such as fructooligosaccharides (FOS) and inulin that improve host health by stimulating the growth and activity of bacteria present in the colon (Gibson \& Roberfroid, 1995). Those bacteria are known as probiotics (Kailasapathy \& Chin, 2000). The most common probiotics are lactic acid bacteria (LAB) and bifidobacteria (Huebner, Wehling, \& Hutkins, 2007; Khurana \& Kanawjia, 2007; Ötles, Çagınd1, \& Akçiçek, 2003). The combination of prebiotics and probiotics which is called synbiotics can be used to manage the microflora in the gut, and enhance survival of probiotics by stimulating growth/activity of bacteria in the colon by prebiotics (Gibson \& Roberfroid, 1995; Khurana \& Kanawjia, 2007). Examples of synbiotics are bifidobacteria (probiotics) and FOS (prebiotics) as well as lactobacilli and lactitol (Collins \& Gibson, 1999). Both prebiotics and probiotics are mostly used in fermented dairy products like functional food product worldwide. Therefore, more research is needed to develop new high value bio products and increase their potential use in functional foods or nutaceuticals (Figueroa-Gonzzalez, Quijano, Ramirez, \& Cruz-Guerrero, 2010).

The objectives of this study were to i) evaluate probiotic potentials of raspberry and strawberry addition in yogurts, ii) investigate antioxidant activity of microwave extracts of the both fruits using ORAC, DPPH, and iii) determine the TPC values of berries. The probiotic potentials of those fruit addition into yogurts containing 
different probiotics were determined by viable microbe count in each yogurt treatment using selective media, $\mathrm{pH}$ and total titratable acidity (TTA) during 28 days at $4{ }^{\circ} \mathrm{C}$.

\section{Materials and Methods}

\subsection{Materials}

Solvents methanol, acetone, HCL, ethyl alcohol, was analytical grade and purchased from Caledon Laboratories LTC (Georgetown, ON, Canada). Monobasic and dibasic potassium phosphate, fluorescein, Trolox (6-hydroxy-2,5,7,8-tetramethylchroman-2-carboxylic acid), rutin, 2,2'-azobis(2-methylpropionamidine) dihydrochloride (AAPH), Folin-Ciocalteu (FC) reagent, and 2,2-diphenyl-1-picryhydrazyl radical (DPPH), $\mathrm{NaOH}$ Gallic acid standard (99\% purity), Tween ${ }^{\circledR} 80$ and phenolphthalein were obtained from Sigma (Oakville, ON, Canada). Sodium carbonate, sodium propionate was obtained from Church and Dwight Canada Corp. (Mississauga, ON, Canada). Peptone, yeast extract powder $(\mathrm{pH} 7.0 \pm 0.5$ ), sodium acetate anhydrous, ammonium citrate (dibasic), magnesium sulfate, manganese sulfate, agar, lithium chloride, sodium hydroxide micro pearls were purchased from BioShop ${ }^{\circledR}$ Canada Inc. (Burlington, ON). D- $(+)$ - Trehalose dehydrate, meat extract was obtained from EMD Chemicals Inc. (Gibbstown, NJ). Difco TM Lactobacilli MRS Agar was obtained from Becton, Dickinson and Company (Sparks, MD). M17 agar, lactose bacteriological grade, MRS broth (de man, Rogosa, Sharpe), M17 broth, anaerobic indicator, Anaerogen ${ }^{\mathrm{TM}}$, the starter cultures of Lactobacillus delbrueckii subsp. bulgaricus (B-548; USDA) and Streptococcus salivarius subsp. thermophilus (14485; ATCC) and the probiotics of Lactobacillus acidophilus (B-4495; USDA) and Bifidobacterium lactis (41405; USDA) were purchased from Oxoid Ltd. (Basingstoke, UK).

\subsection{Probiotic Activity}

\subsubsection{Selecting Berry Concentration}

Raspberry and strawberries were provided by Dentz Orchards in Ottawa, Canada. For determining appropriate berry concentrations of raspberry and strawberry that could be added into yogurt without causing syneresis was determined by preliminary testing. Whole fruits were crushed and homogenized in a fruit blender (Black \& Decker, WI, USA). Individual concentrations of 3, 4 and 5\% of raspberry (Figure 1A) and strawberry (Figure 1B) were added to $50 \mathrm{~mL}$ of pasteurized milk with starter cultures. The tubes were incubated at $42^{\circ} \mathrm{C}$ until yogurt was formed (Espírito Santo et al., 2010). All yogurt treatments of varying berry concentrations were carried out in triplicate.

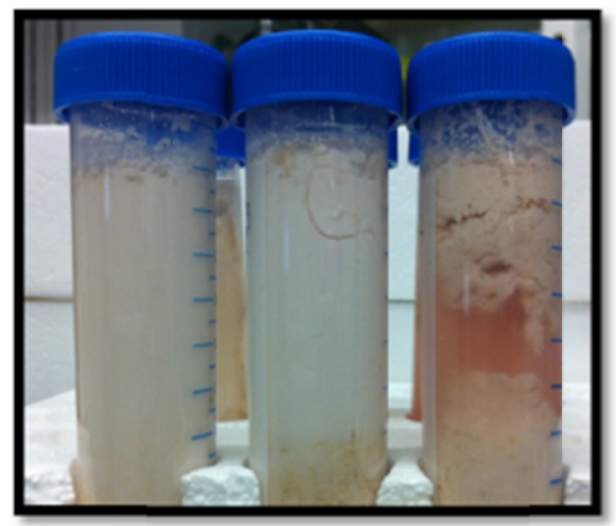

A) 3
4 5

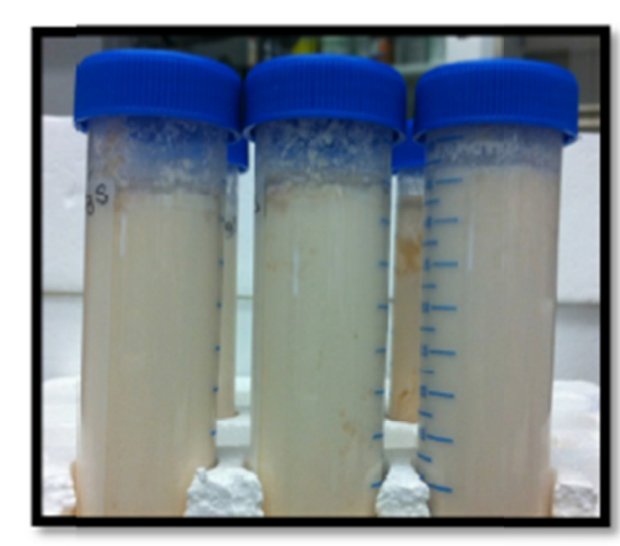

B) 3
4
5

Figure 1. Yogurts with varying concentrations (3\%, $4 \%$ and $5 \%)$ of A) raspberry and B) strawberry

\subsubsection{Microbial Cultures}

MRS broth was used to grow Lactobacillus delbrueckii subsp. Bulgaricus (yogurt starter), and Lactobacillus acidophilus (probiotic 1) as well as Bifidobacterium lactis (probiotic 2). M17 broth was used to grow Streptococcus salivarius subsp. Thermophiles (yogurt starter). For each test tube, $200 \mu \mathrm{L}$ of bacterial culture and $10 \mathrm{~mL}$ of corresponding broth was added and incubated at $37{ }^{\circ} \mathrm{C}$ overnight in a shaker. The test tubes were centrifuged at $4000 \mathrm{rpm}$ for 20 minutes at room temperature $\left(23^{\circ} \mathrm{C}\right)$ and the supernatant was decanted and 10 $\mathrm{mL}$ of sterile water was added to rinse the bacteria. After repeating the same steps twice, the supernatant was 
decanted and $5 \mathrm{~mL}$ of sterile water was added. A hemacytometer was used to count the bacteria until a concentration of about $6.5 \log \mathrm{cfu} / \mathrm{mL}$ was reached.

\subsubsection{Yogurt Preparations}

Homogenized (3.25\%) milk (commercial source in Ottawa, ON) was heated until the temperature reached $85{ }^{\circ} \mathrm{C}$ for 15 minutes. Then, the pasteurized milk was cooled in a water bath and kept at $42{ }^{\circ} \mathrm{C}$ (Espírito Santo et al., 2010). Twelve different yogurt treatments were prepared; 4 with raspberry, 4 with strawberry and 4 without berry (control) as shown in Table 1. For each test tube, $50 \mathrm{~mL}$ of pasteurized milk and $1 \mathrm{~mL}$ of starter culture (microorganism diluted with milk) was added. The probiotics $(1 \mathrm{~mL})$ were added to the respective yogurt treatments as presented in Table 1 . The treatments were incubated at $42{ }^{\circ} \mathrm{C}$ until yogurt was formed, once formed the tubes were stored at $4{ }^{\circ} \mathrm{C}$ in the fridge. All analyses were made in triplicate.

Table 1. The experimental design used to evaluate the effects of raspberry and strawberry addition on probiotic viability in different yogurt trials

\begin{tabular}{|c|c|}
\hline Yogurt trials* & Sample coding \\
\hline $\mathrm{Y}$ & 1 \\
\hline $\mathrm{Y}+$ Pro 1 & 2 \\
\hline $\mathrm{Y}+$ Pro 2 & 3 \\
\hline $\mathrm{Y}+$ Pro $1+$ Pro 2 & 4 \\
\hline $\mathrm{Y}+\mathrm{R}$ & $1 \mathrm{R}$ \\
\hline $\mathrm{Y}+\mathrm{R}+$ Pro 1 & $2 \mathrm{R}$ \\
\hline $\mathrm{Y}+\mathrm{R}+\operatorname{Pro} 2$ & $3 \mathrm{R}$ \\
\hline $\mathrm{Y}+\mathrm{R}+$ Pro $1+$ Pro 2 & $4 \mathrm{R}$ \\
\hline $\mathrm{Y}+\mathrm{S}$ & $1 \mathrm{~S}$ \\
\hline $\mathrm{Y}+\mathrm{S}+$ Pro 1 & $2 \mathrm{~S}$ \\
\hline $\mathrm{Y}+\mathrm{S}+\operatorname{Pro} 2$ & $3 \mathrm{~S}$ \\
\hline $\mathrm{Y}+\mathrm{S}+$ Pro $1+$ Pro 2 & $4 \mathrm{~S}$ \\
\hline
\end{tabular}

${ }^{*} \mathrm{Y}=$ standard yogurts containing only starter cultures of Lactobacillus bulgaricus and Streptococcus thermophiles. Pro1= probiotic Lactobacillus acidophilus, Pro 2=probiotic Bifidobacterium lactis, $\mathrm{R}=$ raspberry, $\mathrm{S}=$ strawberry.

\subsubsection{Microbiological Analyses}

Viable bacteria counts were performed on day 1, 7, 14, 21 and 28 in triplicate by following the study of Espírito Santo et al. (2010). Serial dilutions $\left(10^{-1}\right.$ to $\left.10^{-5}\right)$ were made for each yogurt treatment using a 1: 9 ratio. For each dilution, $10 \mu \mathrm{L}$ was plated onto agar dishes using the spread plate method.

The starter cultures and probiotics were enumerated on selective media according to the method by Vinderola et al. (1999). L. delbrueckiii subsp bulgaricus was enumerated on MRS (pH 5.4) agar and grown under aerobic conditions for 72 hours at $42^{\circ} \mathrm{C}$ (Gonçalves, Freitas, Nero, \& Carvalho, 2009; Vinderola \& Reinheimer, 1999). S. thermophilus was enumerated on M17 agar and grown under aerobic conditions for 24 hours at $37{ }^{\circ} \mathrm{C}$ (Vinderola \& Reinheimer, 1999). L. acidophilus was enumerated on T-MRS agar and grown under aerobic conditions for 48 hours at $37{ }^{\circ} \mathrm{C}$ (Vinderola \& Reinheimer, 1999). B. lactis was enumerated on LP-MRS agar and grown under anaerobic conditions in BBL GasPak ${ }^{\mathrm{TM}}$ System (GasPak System-Oxoid, Basingstoke, UK) for 48 hours at $37^{\circ} \mathrm{C}$ (Vinderola \& Reinheimer, 1999). The number of colonies was counted and the number of cells was converted into log cfu (colony forming units) per $\mathrm{mL}$.

\subsection{5 $\mathrm{pH}$ and TTA}

Both $\mathrm{pH}$ and TTA values of each yogurt treatment (Table 1) was measured on day 1, 7, 14, 21 and 28 according to the method by Espírito Santo et al. (2010). The $\mathrm{pH}$ was measured using the Denver Instrument UB-5 pH meter. TTA value was determined by mixing of $1 \mathrm{~mL}$ of yogurt with $9 \mathrm{~mL}$ of sterile water (1:9) which was titrated with $0.1 \mathrm{M} \mathrm{NaOH}$ and $0.1 \%$ phenolphthalein colour indicator (Behrad, Yusof, Goh, \& Baba, 2009). The amount of acid produced during fermentation was expressed as TTA\%. All analyses were made in triplicate. 


\subsection{Antioxidant Activity Analysis}

\subsubsection{Microwave Extraction of Water Extractable Material (WEM)}

Raspberries and strawberries were crushed using a juice processor and stored in Ziploc bags in the freezer at -20 ${ }^{\circ} \mathrm{C}$ prior to analysis. WEM was extracted by using microwave. The samples ( $5 \mathrm{~g}$ of each berry samples) and 50 $\mathrm{mL}$ of distilled water were added into a quartz vessel and placed into the CEM STAR System 2 microwave digestion system (CEM Corporation, Matthews, NC, USA) at $90{ }^{\circ} \mathrm{C}$ for 30 minutes. The mixture was then cooled and centrifuged at $4000 \mathrm{rpm}$ for 20 minutes at room temperature $\left(23^{\circ} \mathrm{C}\right)$. The supernatant was collected and stored at $-20^{\circ} \mathrm{C}$ in the freezer until further analysis (Liazid, Palma, Brigui, \& Barroso, 2007). All analyses were made in triplicate.

\subsubsection{ORAC}

The antioxidant activity of raspberry and strawberry WEM was measured using ORAC assay by following the procedures of Huang et al. (2002) and Hosseinian et al. (2007). The FLx $800^{\mathrm{TM}}$ Multi-Detection Microplate Reader with Gen $5^{\mathrm{TM}}$ software by BioTek Instruments was used to carry out the assay. Basically it consists of using 2,2'-Azobis (2-amidinopropane) dihydrochloride (AAPH) as the free radical generator, Trolox (water-soluble $\alpha$-tocopheral (Vitamin E) analogue) as the standard and fluorescein working solution as the fluorescent probe (Huang, Ou, Hampsch-Woodill, Flanagan, \& Prior, 2002; Wang \& Lin, 2000). Five different concentrations of Trolox standard $(6.25,12.5,25,50$ and $100 \mu \mathrm{M})$ and two concentrations $(200$ and $100 \mu \mathrm{M})$ of rutin control were prepared. For each ORAC run, a 96 micro-well plate was prepared; including $20 \mu \mathrm{L}$ of buffer (blank), Trolox (standards), sample, and rutin was loaded into designated wells. In each well, $120 \mu \mathrm{L}$ of fluorescein working solution was added to incubate at $37^{\circ} \mathrm{C}$ for $20 \mathrm{~min}$. Then, $60 \mu \mathrm{L}$ of AAPH peroxyl radical generator was added into each well to make a total well volume of $200 \mu \mathrm{L}$. The fluorometric microplate reader was used at an excitation wavelength and emission wavelength of $485 \mathrm{~nm}$ and $528 \mathrm{~nm}$, respectively. The ORAC value was calculated by using the area under the curve (Net AUC) of the sample and the equation of the line from the Trolox standard curve. ORAC values were expressed as micromole Trolox Equivalents/100 g berry. All analyses were carried out in triplicate.

\subsubsection{DPPH}

The antioxidant activity of raspberry and strawberry WEM was determined using the DPPH scavenging activity assay (Li, Hydamaka, Lowry, \& Beta, 2009). Briefly, $200 \mu \mathrm{L}$ of sample was mixed with $3.8 \mathrm{~mL}$ of DPPH solution $(60 \mu \mathrm{M})$. The absorbance (A) of the mixture was measured at a wavelength of $515 \mathrm{~nm}$ at $0,5,10,15,20$, 30, 40, 50, 60 minutes using the UV-Visible SpectraMax Plus384 spectrophotometer in triplicate. Absorbance was measured against a blank of methanol. The antioxidant activity was calculated as percent discoloration as shown in the following equation. All analyses were made in triplicate.

$$
\% D P P H=\left(1-\left[\frac{A_{\text {sample }}}{A_{\text {control } t=0}}\right]\right) \times 100
$$

\subsubsection{Extraction of Phenolics and TPC Analysis}

Extraction: Phenolic compounds from raspberry and strawberry were extracted according to the method of Li et al. (2009). Each berry sample $(1.0 \mathrm{~g})$ was mixed with $15 \mathrm{~mL}$ of ethanol $(95 \%) / 1 \mathrm{~N} \mathrm{HCl}(85: 15, \mathrm{v} / \mathrm{v})$ solution and the mixture was stirred for 6 hours at room temperature $\left(23^{\circ} \mathrm{C}\right)$. Then the mixture was centrifuged at $4,000 \mathrm{rpm}$ for 15 minutes at $5^{\circ} \mathrm{C}$. The supernatant was collected and stored at $-20^{\circ} \mathrm{C}$ in the freezer under further analysis.

TPC analysis: $200 \mu \mathrm{L}$ of each berry extract was mixed with $1.9 \mathrm{~mL}$ of 10 fold diluted FC reagent. After 5 minutes at room temperature $\left(23^{\circ} \mathrm{C}\right), 1.9 \mathrm{~mL}$ of a $60 \mathrm{~g} / \mathrm{L}$ sodium carbonate solution was added. The absorbance was measured after 120 minutes of incubation at room temperature $\left(23^{\circ} \mathrm{C}\right)$ at $725 \mathrm{~nm}$ against a blank of distilled water using the UV-Visible SpectraMax Plus384 spectrophotometer. The absorbance was measured in triplicate and the results were expressed as gallic acid equivalents per gram of sample.

\subsection{Statistical Analyses}

All experiments were conducted in triplicates by means of Analysis of variance (ANOVA) with Statistical Analysis System (SAS, version 9.2, SAS Institute Inc., Cary, NC). Duncan's Multiple Range test was used when significant $(\mathrm{P}<0.05)$ mean comparison was performed. 


\section{Results and Discussion}

\subsection{Probiotic Activity}

\subsubsection{Berry Concentrations}

The best raspberry and strawberry concentration that could be added into milk was determined by adding different amount of berry to milk and maintain a stable yogurt product that would be acceptable to the consumers as palatable yogurt (Espírito Santo et al., 2010). Therefore, 3\% berry addition in yogurt was determined as the best concentration to be employed for the all yogurt trials (Table 1) since there was no sign of syneresis (separation of water from gel) (Figure 1A and B).

\subsubsection{Viable Microorganism Counts With Selective Media}

The viable microorganism counts of Streptococcus thermophilus and Lactobacillus delbruekii subsp. bulgaricus in all yogurt trials (Table 1) are shown in Table 2 as $\log \mathrm{cfu} \mathrm{mL}^{-1}$. Both counts showed no significant $(\mathrm{P}<0.05)$ difference among treatments (Table 2) after 1 day of cold storage and varied from 7.18 to $7.82 \log \mathrm{cfu} \mathrm{mL}^{-1}$.

Table 2. Streptococcus thermophilus and Lactobacillus delbruekii subsp. bulgaricus counts (log cfu $\left.\mathrm{mL}^{-1}\right)$ in control (1-4), raspberry (1R-4R) and strawberry (1S-4S) yogurts

\begin{tabular}{|c|c|c|c|c|c|}
\hline Samples* & Day 1 & Day 7 & Day 14 & Day 21 & Day 28 \\
\hline \multicolumn{6}{|c|}{ S.thermophilus } \\
\hline 1 & $7.73^{\mathrm{a}}$ & $7.96^{\mathrm{a}}$ & $7.57^{\mathrm{ab}}$ & $8.17^{\mathrm{abc}}$ & $7.88^{\mathrm{ab}}$ \\
\hline 2 & $7.68^{\mathrm{a}}$ & $7.84^{\mathrm{ab}}$ & $7.49^{\mathrm{ab}}$ & $7.85^{\mathrm{cd}}$ & $8.03^{\mathrm{a}}$ \\
\hline 3 & $7.38^{\mathrm{a}}$ & $7.49^{\mathrm{bcd}}$ & $7.51^{\mathrm{ab}}$ & $8.00^{\mathrm{bcd}}$ & $7.99^{\mathrm{a}}$ \\
\hline 4 & $7.18^{\mathrm{a}}$ & $7.64^{\mathrm{abc}}$ & $7.69^{\mathrm{ab}}$ & $8.15^{\mathrm{abc}}$ & $7.95^{\mathrm{a}}$ \\
\hline $1 \mathrm{R}$ & $7.29^{\mathrm{a}}$ & $6.73^{\mathrm{f}}$ & $8.13^{\mathrm{a}}$ & $8.51^{\mathrm{a}}$ & $8.08^{\mathrm{a}}$ \\
\hline $2 \mathrm{R}$ & $7.39^{\mathrm{a}}$ & $7.43^{\mathrm{cd}}$ & $7.59^{\mathrm{ab}}$ & $8.38^{\mathrm{ab}}$ & $8.22^{\mathrm{a}}$ \\
\hline $3 \mathrm{R}$ & $7.67^{\mathrm{a}}$ & $7.23^{\mathrm{de}}$ & $7.44^{\mathrm{b}}$ & $8.55^{\mathrm{a}}$ & $8.14^{\mathrm{a}}$ \\
\hline $4 \mathrm{R}$ & $7.68^{\mathrm{a}}$ & $7.63^{\mathrm{abc}}$ & $7.75^{\mathrm{ab}}$ & $8.41^{\mathrm{ab}}$ & $8.05^{\mathrm{a}}$ \\
\hline $1 \mathrm{~S}$ & $7.45^{\mathrm{a}}$ & $7.01^{\mathrm{ef}}$ & $7.44^{\mathrm{b}}$ & $7.65^{\mathrm{de}}$ & $8.13^{\mathrm{a}}$ \\
\hline $2 \mathrm{~S}$ & $7.55^{\mathrm{a}}$ & $7.32^{\text {cde }}$ & $7.52^{\mathrm{ab}}$ & $7.42^{\mathrm{ef}}$ & $7.60^{\mathrm{bc}}$ \\
\hline $3 \mathrm{~S}$ & $7.59^{\mathrm{a}}$ & $7.54^{\mathrm{bcd}}$ & $7.49^{\mathrm{ab}}$ & $7.61^{\mathrm{def}}$ & $8.04^{\mathrm{a}}$ \\
\hline $4 \mathrm{~S}$ & $7.82^{\mathrm{a}}$ & $7.16^{\mathrm{de}}$ & $7.41^{\mathrm{b}}$ & $7.23^{\mathrm{f}}$ & $7.31^{\mathrm{c}}$ \\
\hline \multicolumn{6}{|c|}{ L.bulgaricus } \\
\hline 1 & $7.60^{\mathrm{a}}$ & $7.70^{\mathrm{b}}$ & $7.04^{d}$ & $7.50^{\mathrm{abc}}$ & $7.66^{\mathrm{ab}}$ \\
\hline 2 & $7.18^{\mathrm{a}}$ & $7.36^{\mathrm{b}}$ & $8.14^{\mathrm{bc}}$ & $7.75^{\mathrm{abc}}$ & $8.18^{\mathrm{a}}$ \\
\hline 3 & $7.28^{\mathrm{a}}$ & $7.40^{\mathrm{b}}$ & $7.95^{\mathrm{c}}$ & $7.66^{\mathrm{abc}}$ & $7.73^{\mathrm{ab}}$ \\
\hline 4 & $7.18^{\mathrm{a}}$ & $7.58^{\mathrm{b}}$ & $8.18^{\mathrm{bc}}$ & $8.10^{\mathrm{a}}$ & $7.80^{\mathrm{ab}}$ \\
\hline $1 \mathrm{R}$ & $7.29^{\mathrm{a}}$ & $8.37^{\mathrm{a}}$ & $8.90^{\mathrm{a}}$ & $7.98^{\mathrm{ab}}$ & $8.03^{\mathrm{ab}}$ \\
\hline $2 \mathrm{R}$ & $7.39^{\mathrm{a}}$ & $8.41^{\mathrm{a}}$ & $8.71^{\mathrm{ab}}$ & $7.94^{\mathrm{ab}}$ & $7.61^{\mathrm{ab}}$ \\
\hline $3 \mathrm{R}$ & $7.67^{\mathrm{a}}$ & $8.44^{\mathrm{a}}$ & $8.52^{\mathrm{abc}}$ & $8.06^{\mathrm{ab}}$ & $7.73^{\mathrm{ab}}$ \\
\hline $4 \mathrm{R}$ & $7.68^{\mathrm{a}}$ & $8.49^{\mathrm{a}}$ & $8.40^{\mathrm{abc}}$ & $7.96^{\mathrm{ab}}$ & $7.94^{\mathrm{ab}}$ \\
\hline $1 \mathrm{~S}$ & $7.45^{\mathrm{a}}$ & $8.62^{\mathrm{a}}$ & $8.20^{b c}$ & $7.73^{\mathrm{abc}}$ & $7.90^{\mathrm{ab}}$ \\
\hline $2 \mathrm{~S}$ & $7.75^{\mathrm{a}}$ & $8.40^{\mathrm{a}}$ & $7.85^{\mathrm{c}}$ & $7.30^{\mathrm{c}}$ & $7.43^{\mathrm{b}}$ \\
\hline $3 \mathrm{~S}$ & $7.49^{\mathrm{a}}$ & $8.51^{\mathrm{a}}$ & $8.07^{\mathrm{bc}}$ & $7.53^{\mathrm{abc}}$ & $7.66^{\mathrm{ab}}$ \\
\hline $4 \mathrm{~S}$ & $7.82^{\mathrm{a}}$ & $8.40^{\mathrm{a}}$ & $7.86^{\mathrm{c}}$ & $7.43^{b c}$ & $7.62^{\mathrm{ab}}$ \\
\hline
\end{tabular}

*1-4=control yogurts containing no berry, 1R-4R=yogurts containing raspberry, 1S-4S=yogurts containing strawberry. Lactobacillus acidophilus (probiotic 1) added yogurts (2, 4, 2R, 2S, 4R, 4S), and Bifidobacterium 
lactis (probiotic 2) added yogurts $(3,4,3 \mathrm{R}, 3 \mathrm{~S}, 4 \mathrm{R}, 4 \mathrm{~S})$. cfu =colony forming units. Different letters in columns in the same day are significantly different $(P<0.05)$ in Duncan's multiple range tests.

At day 7, L.bugaricus counts in both berry containing yogurts were significantly $(\mathrm{P}<0.05)$ higher than the control yogurts just to the opposite of S.thermophilus counts. At day 14, L.bulgaricus counts in yogurts containing raspberry (1R), raspberry with $L$. acidophilus (2R) and strawberry (1S) were significantly higher $(\mathrm{P}<0.05)$ than the control. At day 21, S.thermophilus counts were significantly higher $(\mathrm{P}<0.05)$ in treatments that contained raspberry and L. acidophilus $(2 \mathrm{R})$ and raspberry and B. lactis (3R). Meanwhile, L.bulgaricus count on the same day for strawberry yogurts with the exception of strawberry and B. lactis (3S) were significantly lower $(\mathrm{P}<0.05)$ than the control and there was not a significant difference $(\mathrm{P}<0.05)$ in treatments containing raspberry. The treatment containing strawberry and both probiotics (4S) was significantly lower than the control. At day 28 , the counts of $S$. thermophilus ranged from 8.05 to $8.22 \mathrm{log}$ cfu mL $\mathrm{mL}^{-1}$ in raspberry yogurts, 7.31 to $8.13 \mathrm{log}$ cfu $\mathrm{mL}^{-1}$ in strawberry yogurts and 7.88 to $8.04 \log \mathrm{cfu} \mathrm{mL}^{-1}$ in the controls. There was not a significant difference (P $<0.05)$ in treatments that contained raspberry. Treatments that contained strawberry and L. acidophilus $(2 \mathrm{~S})$ and strawberry with both probiotics $(4 \mathrm{~S})$ were significantly lower $(\mathrm{P}<0.05)$ than the control.

The viable microbial counts of each probiotic- $1(2,2 \mathrm{R}, 2 \mathrm{~S})$ and probiotic- $2(3,3 \mathrm{R}, 3 \mathrm{~S})$ and both probiotics $(4$, $4 \mathrm{R}, 4 \mathrm{~S})$ in yogurt trials during 28 days of cold storage were shown in Figure 2 and Figure 3. On day 1, for yogurts containing raspberry and strawberry, there was not a significant difference $(\mathrm{P}<0.05)$ on the growth of probiotic-1 compared to the control yogurts, the counts of $L$. acidophilus ranged from 6.37 to $6.39 \log$ cfu mL $\mathrm{mL}^{-1}$ in yogurts containing raspberry, and 6.33 to $6.40 \mathrm{log}$ cfu $\mathrm{mL}^{-1}$ in yogurts containing strawberry and 5.78 to 6.30 $\log \mathrm{cfu} \mathrm{mL} \mathrm{m}^{-1}$ in the control (Figure 2). The counts of B. lactis ranged from 6.30 to $6.54 \log \mathrm{cfu} \mathrm{mL} \mathrm{m}^{-1}$ in yogurts containing raspberry, 6.20 to $6.56 \log$ cfu mL $\mathrm{m}^{-1}$ in yogurts containing strawberry and 6.58 to $6.68 \log \mathrm{cfu} \mathrm{mL}^{-1}$ in the control (Figure 3 ). The counts in yogurt containing strawberry and B. lactis (3S) was significantly lower $(\mathrm{P}<0.05)$ than the control. There was not a significant difference $(\mathrm{P}<0.05)$ in treatments containing berry and both probiotics compared to the control. At day 7, the counts of L. acidophilus in yogurt containing raspberry and strawberry and L. acidophilus ( $2 \mathrm{R}$ and $2 \mathrm{~S}$ ) and in yogurts containing berry with both probiotics (4R and 4S) were significantly higher $(\mathrm{P}<0.05)$ than the control. The counts of $B$. lactis in yogurts containing raspberry and strawberry and $B$. lactis $(3 \mathrm{R}$ and $3 \mathrm{~S})$ were not significantly different $(\mathrm{P}<0.05)$ from the control. $B$. lactis counts in yogurt containing berry with both probiotics $(4 \mathrm{R}$ and $4 \mathrm{~S})$ were significantly higher $(\mathrm{P}<0.05)$ than the control. At day 14 , the counts of $L$. acidophilus in yogurt containing raspberry and L. acidophilus $(2 \mathrm{R})$ was significantly higher $(\mathrm{P}<0.05)$ compared to the control. There was not a significant difference $(\mathrm{P}<0.05)$ in L. acidophilus counts in yogurt containing berry with both probiotics (4R and 4S) compared to the control. The counts of $B$. lactis in yogurt containing raspberry and $B$. lactis $(3 \mathrm{R})$ was significantly higher $(\mathrm{P}<0.05)$ than the control. $B$. lactis counts in yogurt containing berry with both probiotics (4R and $4 \mathrm{~S})$ was not significantly different $(\mathrm{P}<0.05)$ compared to the control.

Probiotic-1 (Lactobacillus acidophilus) count

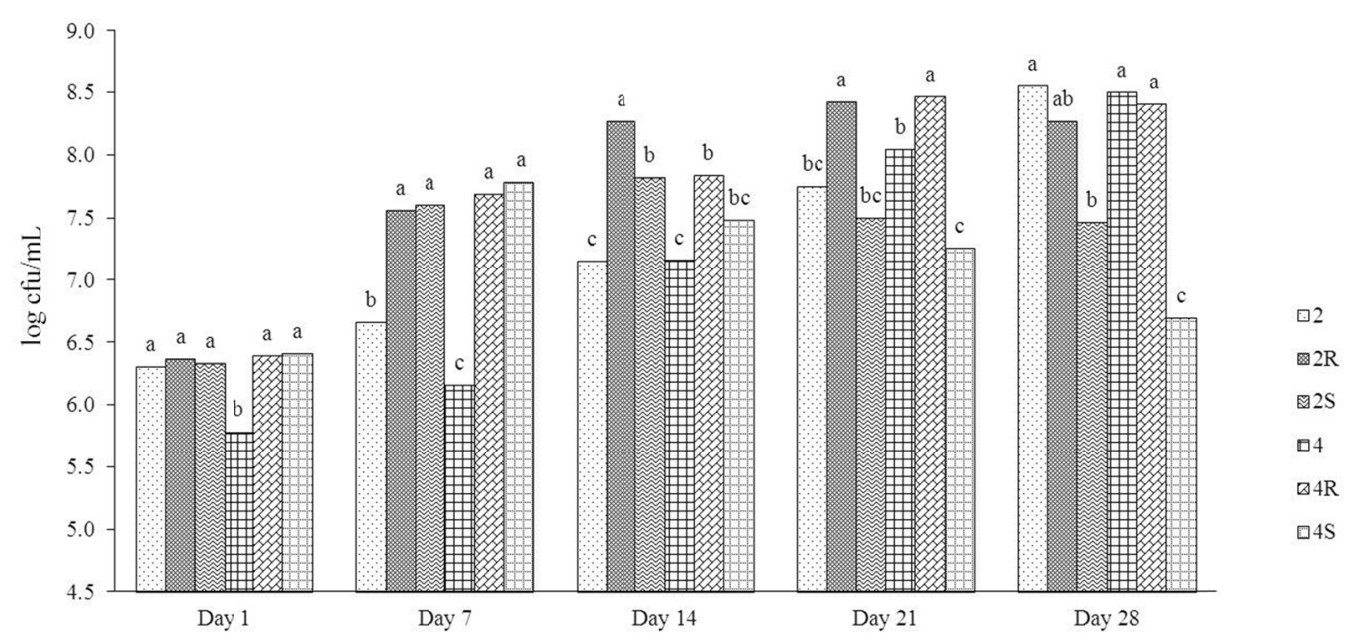

Figure 2. Probiotic 1-Lactobacillus acidophilus counts in control $(2,4)$, raspberry $(2 \mathrm{R}, 4 \mathrm{R})$ and strawberry $(2 \mathrm{~S}$, $4 \mathrm{~S})$ yogurts over 28 days of cold storage at $4{ }^{\circ} \mathrm{C}$ 


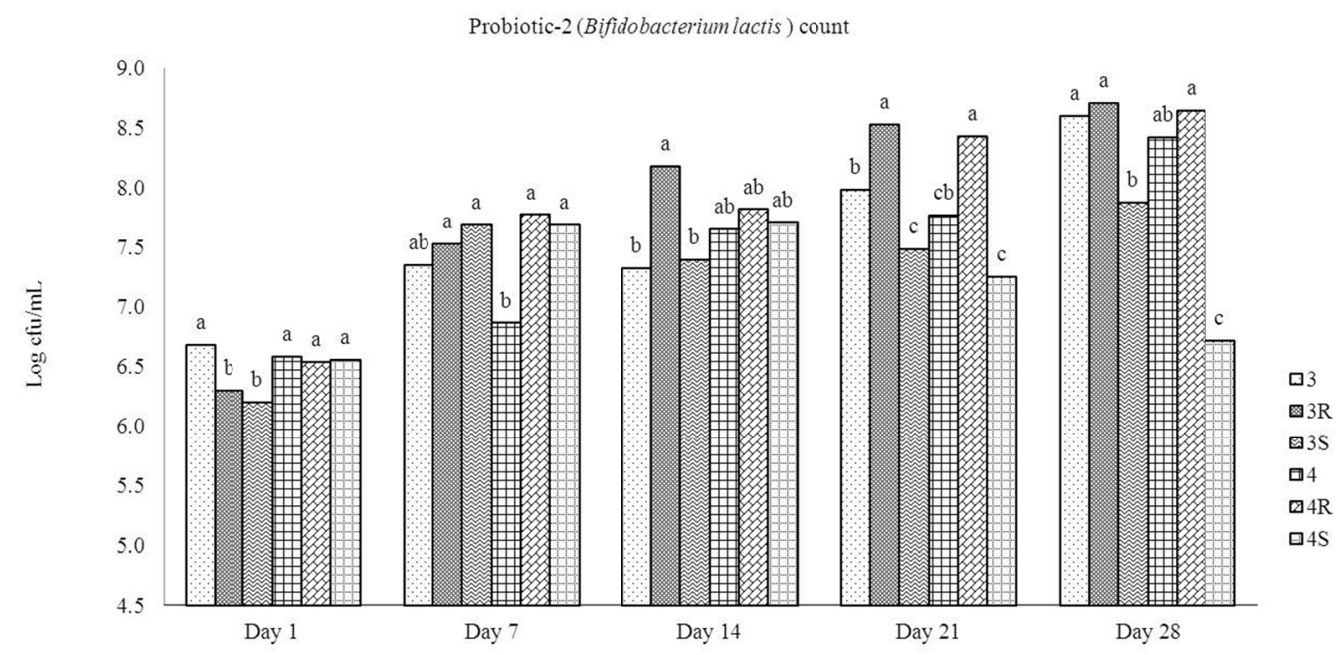

Figure 3. Probiotic 2-Bifidobacterium lactis counts in control $(3,4)$, raspberry $(3 \mathrm{R}, 4 \mathrm{R})$ and $(3 \mathrm{~S}, 4 \mathrm{~S})$ yogurts over 28 days of cold storage at $4{ }^{\circ} \mathrm{C}$

At day 21 , the counts of L. acidophilus in yogurt containing raspberry and L. acidophilus and (2R) was significantly higher $(\mathrm{P}<0.05)$ than the control. L. acidophilus counts were significantly lower $(\mathrm{P}<0.05)$ in yogurt containing strawberry and both probiotics $(4 \mathrm{~S})$. The counts of $B$. lactis in yogurt containing raspberry and $B$. lactis $(3 \mathrm{R})$ and raspberry with both probiotics $(4 \mathrm{R})$ was significantly higher $(\mathrm{P}<0.05)$ than the control. At day 28 , the counts of L. acidophilus ranged from 8.27 to $8.40 \mathrm{log} \mathrm{cfu} \mathrm{mL}^{-1}$ in yogurts containing raspberry, 6.69 to 7.46 $\log \mathrm{cfu} \mathrm{mL}^{-1}$ in yogurts containing strawberry and 8.50 to $8.55 \log \mathrm{cfu} \mathrm{mL}^{-1}$ in the control. Counts were significantly lower $(\mathrm{P}<0.05)$ in yogurt containing strawberry and $L$. acidophilus $(2 \mathrm{~S})$ and strawberry and both probiotics (4S). The counts of $B$. lactis ranged from 8.65 to $8.72 \log \mathrm{cfu} \mathrm{mL}^{-1}$ in yogurts containing raspberry, 6.72 to $7.88 \log \mathrm{cfu} \mathrm{mL} L^{-1}$ in yogurts containing strawberry and 8.43 to $8.60 \log \mathrm{cfu} \mathrm{mL} \mathrm{m}^{-1}$ in the control. Yogurt containing strawberry and $B$. lactis $(3 \mathrm{~S})$ and strawberry and both probiotics $(4 \mathrm{~S})$ were significantly lower $(\mathrm{P}<0.05)$ than the control. From day 21 to 28 , the counts of probiotics in treatments containing strawberry were lower than the control. At the end of 28 days of cold storage, the counts of probiotics in the control and yogurts containing berry were above $6 \log \mathrm{cfu} \mathrm{mL} \mathrm{L}^{-1}$. The counts of probiotics should range from 6 to $8 \mathrm{cfu} \mathrm{mL}^{-1}$ which is the recommended amount that should remain at the end of cold storage (Vasiljevic \& Shah, 2008). Compounds such as the nutrients in the berries may act as prebiotic substrates and possibly stimulate the growth of microorganisms and their viability. The counts of $L$. acidiphulis were positively correlated $(\mathrm{r}=0.89$, Figures 2 and 3) with B. lactis from day 7 to 28 . Moreover, the starter of Lactobacillus delbruekii subsp. bulgaricus was positively correlated ( $\mathrm{r}=0.72$, Table 2 , Figures 2$)$ with probiotic 1 (L. acidiphulis).

There are studies which show that the addition of fruit pulp increase the counts of probiotic bacteria. In a study by Espírito Santo et al. (2010), the effect of açai addition into yogurts containing different probiotic bacteria; Lactobacillus acidophilus L10, Bifidobacterium animalis ssp. lactis B104 and Bifidobacterium longum B105 and Bidfidobacterium anaimalis ssp. lactis B94 were investigated. The addition of açai favoured the increase of Lactobacillus acidophilus L10, Bifidobacterium animalis ssp. lactis B104 and Bifidobacterium longum B105 with values of 7.65, 9.36 and $5.42 \mathrm{log}$ cfu $\mathrm{mL}^{-1}$ respectively (Espírito Santo et al., 2010). In another study, the addition of dietary fibers from apple, banana and passion fruit into yogurt containing different probiotic bacteria; Lactobacillus acidophilus L10 and Bifidobacterium animalis subsp. lactis B104, HN019 and B94 were investigated (Espírito Santo et al., 2011). Probiotic viability increased in B. animalis subsp. lactis B104, HN019 and B94 as well as Lactobacillus acidophilus L10 with apple and banana fiber addition (Espírito Santo et al., 2010). In a study by Kailasapathy et al. (2008), the effect of mango, mixed berry, passion fruit and strawberry addition into yogurt containing the probiotic bacteria Lactobacillus acidophilus L10 and Bifidobacterium animalis ssp. lactis B94 were investigated. The addition of $10 \mathrm{~g} / 100 \mathrm{~g}$ of passion fruit or mixed berry had an effect on L. acidophilus L10 (Kailasapathy, Harmstorf, \& Phillips, 2008).

There are various factors that affect the viability of probiotic bacteria in yogurt which include the inoculum level, temperature, length of fermentation as well as the strains of microorganisms used (Kailasapathy \& Chin, 2000). L. acidophilus and Bifidobacterium are affected by oxygen; these microorganisms do not have an 
electron-transport chain which means that oxygen is not going to be reduced properly and exposure to oxygen can lead to cell death due to metabolite accumulation (Talwalkar \& Kailasapathy, 2004). The growth of bifidobacteria can be affected by other microorganisms that are present within the yogurt which can possible restrict its growth (Kailasapathy \& Chin, 2000). The decrease could also be due to a reduction in sugars present in the yogurt which in turn provides fewer nutrients for the bacteria to consume (Agil \& Hosseinian, 2012).

\subsection{3 $\mathrm{pH}$ and TTA}

Probiotic bacteria produce various acids such as butyric, lactic and propionic acid with lactic acid being the most prevalent (Agil \& Hosseinian, 2012). On day 1, the pH among all yogurt treatments ranged from 6.16 to 6.45 (Table 3). Yogurt containing raspberry and B. lactis (3R), strawberry and L. acidophilus (2S), strawberry and B. lactis (3S), strawberry and both probiotics (4S) were significantly lower $(\mathrm{P}<0.05)$ than the control. The TTA\% among all yogurt treatments ranged from 0.13 to 0.20 (Table 4). In yogurt treatments containing raspberry $(1 \mathrm{R}-4 \mathrm{R})$ and strawberry $(1 \mathrm{~S}-4 \mathrm{~S})$, the lactic acid content was significantly higher $(\mathrm{P}<0.05)$ compared to the control.

On day 7, the pH among all yogurt treatments ranged from 6.06 to 6.50 (Table 3). There was not a significant difference $(\mathrm{P}<0.05)$ in $\mathrm{pH}$ among treatments containing berry compared to the control. The TTA\% among all yogurt treatments ranged from 0.16 to 0.25 (Table 4). Yogurt treatments containing raspberry (1R-4R) were significantly higher $(\mathrm{P}<0.05)$ than the control. Yogurt containing strawberry with L. acidophilus $(2 \mathrm{~S})$ and strawberry with both probiotics $(4 \mathrm{~S})$ were significantly higher $(\mathrm{P}<0.05)$ than the control.

On day 14, the $\mathrm{pH}$ among all yogurts treatments ranged from 5.77 to 6.47 (Table 3). Yogurt containing raspberry (1R) had a significantly lower $(\mathrm{P}<0.05) \mathrm{pH}$ than the control. The TTA\% among all yogurt treatments ranged from 0.21 to 0.49 (Table 4). There was a significant higher $(\mathrm{P}<0.05)$ lactic acid content in yogurt containing raspberry with the exception of yogurt with raspberry and both probiotics (4R) compared to the control.

Table 3. The $\mathrm{pH}$ values of control (1-4), raspberry (1R-4R), and strawberry (1S-4S) yogurts

\begin{tabular}{llllll}
\hline Samples* & Day 1 & Day 7 & Day 14 & Day 21 & Day 28 \\
\hline 1 & $6.40^{\text {abc }}$ & $6.56^{\mathrm{a}}$ & $6.47^{\mathrm{a}}$ & $6.30^{\mathrm{ab}}$ & $6.04^{\mathrm{a}}$ \\
2 & $6.30^{\mathrm{cd}}$ & $6.09^{\mathrm{b}}$ & $6.02^{\mathrm{bcd}}$ & $5.90^{\mathrm{bcd}}$ & $5.70^{\mathrm{b}}$ \\
3 & $6.16^{\mathrm{e}}$ & $6.43^{\mathrm{ab}}$ & $6.36^{\mathrm{ab}}$ & $6.30^{\mathrm{ab}}$ & $6.08^{\mathrm{a}}$ \\
4 & $6.23^{\mathrm{ed}}$ & $6.50^{\mathrm{ab}}$ & $6.47^{\mathrm{a}}$ & $6.48^{\mathrm{a}}$ & $6.19^{\mathrm{a}}$ \\
\hline $1 \mathrm{R}$ & $6.38^{\mathrm{abc}}$ & $6.15^{\mathrm{ab}}$ & $5.77^{\mathrm{d}}$ & $5.64^{\mathrm{cd}}$ & $5.12^{\mathrm{c}}$ \\
$2 \mathrm{R}$ & $6.31^{\mathrm{bcd}}$ & $6.11^{\mathrm{b}}$ & $5.88^{\mathrm{cd}}$ & $5.41^{\mathrm{d}}$ & $5.10^{\mathrm{c}}$ \\
$3 \mathrm{R}$ & $6.31^{\mathrm{bcd}}$ & $6.06^{\mathrm{b}}$ & $5.98^{\mathrm{bcd}}$ & $5.58^{\mathrm{cd}}$ & $5.13^{\mathrm{c}}$ \\
$4 \mathrm{R}$ & $6.28^{\mathrm{cd}}$ & $6.12^{\mathrm{ab}}$ & $6.04^{\mathrm{abcd}}$ & $5.53^{\mathrm{cd}}$ & $5.21^{\mathrm{c}}$ \\
\hline $1 \mathrm{~S}$ & $6.45^{\mathrm{a}}$ & $6.22^{\mathrm{ab}}$ & $6.14^{\mathrm{abcd}}$ & $5.84^{\mathrm{bcd}}$ & $5.25^{\mathrm{c}}$ \\
$2 \mathrm{~S}$ & $6.43^{\mathrm{ab}}$ & $6.21^{\mathrm{ab}}$ & $6.11^{\mathrm{abcd}}$ & $5.87^{\mathrm{bcd}}$ & $5.12^{\mathrm{c}}$ \\
$3 \mathrm{~S}$ & $6.4^{\mathrm{abc}}$ & $6.22^{\mathrm{ab}}$ & $6.15^{\mathrm{abcd}}$ & $6.01^{\mathrm{abc}}$ & $5.26^{\mathrm{c}}$ \\
$4 \mathrm{~S}$ & $6.43^{\mathrm{ab}}$ & $6.20^{\mathrm{ab}}$ & $6.24^{\mathrm{abc}}$ & $5.88^{\mathrm{bcd}}$ & $5.10^{\mathrm{c}}$ \\
\hline
\end{tabular}

*1-4=control yogurts containing no berry, 1R-4R=yogurts containing raspberry, 1S-4S=yogurts containing strawberry. Lactobacillus acidophilus (probiotic-1) added yogurts $(2,4,2 \mathrm{R}, 2 \mathrm{~S}, 4 \mathrm{R}, 4 \mathrm{~S})$ and Bifidobacterium lactis (probiotic 2) added yogurts $(3,4,3 \mathrm{R}, 3 \mathrm{~S}, 4 \mathrm{R}, 4 \mathrm{~S})$. Different letters in columns in the same day are significantly different $(\mathrm{P}<0.05)$ in Duncan's multiple range tests. 
Table 4. Total titratable acidity (TTA \%) values of control (1-4), raspberry (1R-4R), and strawberry (1S-4S) yogurts

\begin{tabular}{llllll}
\hline Samples* & Day 1 & Day 7 & Day 14 & Day 21 & Day 28 \\
\hline 1 & $0.14^{\mathrm{bc}}$ & $0.17^{\mathrm{b}}$ & $0.21^{\mathrm{e}}$ & $0.41^{\mathrm{c}}$ & $0.57^{\mathrm{cd}}$ \\
2 & $0.12^{\mathrm{c}}$ & $0.17^{\mathrm{b}}$ & $0.22^{\mathrm{e}}$ & $0.40^{\mathrm{c}}$ & $0.52^{\mathrm{d}}$ \\
3 & $0.13^{\mathrm{c}}$ & $0.16^{\mathrm{b}}$ & $0.24^{\mathrm{de}}$ & $0.40^{\mathrm{c}}$ & $0.52^{\mathrm{d}}$ \\
4 & $0.13^{\mathrm{c}}$ & $0.16^{\mathrm{b}}$ & $0.22^{\mathrm{de}}$ & $0.36^{\mathrm{c}}$ & $0.48^{\mathrm{d}}$ \\
\hline $1 \mathrm{R}$ & $0.20^{\mathrm{a}}$ & $0.25^{\mathrm{a}}$ & $0.45^{\mathrm{ab}}$ & $0.59^{\mathrm{ab}}$ & $0.68^{\mathrm{bc}}$ \\
$2 \mathrm{R}$ & $0.20^{\mathrm{a}}$ & $0.24^{\mathrm{a}}$ & $0.38^{\mathrm{abc}}$ & $0.60^{\mathrm{a}}$ & $0.71^{\mathrm{bc}}$ \\
$3 \mathrm{R}$ & $0.18^{\mathrm{a}}$ & $0.25^{\mathrm{a}}$ & $0.49^{\mathrm{a}}$ & $0.54^{\mathrm{ab}}$ & $0.69^{\mathrm{bc}}$ \\
$4 \mathrm{R}$ & $0.17^{\mathrm{ab}}$ & $0.24^{\mathrm{a}}$ & $0.36^{\mathrm{abcd}}$ & $0.58^{\mathrm{ab}}$ & $0.88^{\mathrm{a}}$ \\
\hline $1 \mathrm{~S}$ & $0.19^{\mathrm{a}}$ & $0.22^{\mathrm{ab}}$ & $0.33^{\mathrm{bcde}}$ & $0.58^{\mathrm{ab}}$ & $0.75^{\mathrm{ab}}$ \\
$2 \mathrm{~S}$ & $0.19^{\mathrm{a}}$ & $0.24^{\mathrm{a}}$ & $0.32^{\mathrm{bcde}}$ & $0.51^{\mathrm{ab}}$ & $0.69^{\mathrm{bc}}$ \\
$3 \mathrm{~S}$ & $0.19^{\mathrm{a}}$ & $0.20^{\mathrm{ab}}$ & $0.30^{\text {cde }}$ & $0.50^{\mathrm{b}}$ & $0.75^{\mathrm{ab}}$ \\
$4 \mathrm{~S}$ & $0.18^{\mathrm{ab}}$ & $0.24^{\mathrm{a}}$ & $0.32^{\mathrm{bcde}}$ & $0.52^{\mathrm{ab}}$ & $0.88^{\mathrm{a}}$ \\
\hline
\end{tabular}

*1-4=control yogurts containing no berry, 1R-4R=yogurts containing raspberry, 1S-4S=yogurts containing strawberry. Lactobacillus acidophilus (probiotic-1) added yogurts $(2,4,2 \mathrm{R}, 2 \mathrm{~S}, 4 \mathrm{R}, 4 \mathrm{~S})$ and Bifidobacterium lactis (probiotic 2) added yogurts $(3,4,3 \mathrm{R}, 3 \mathrm{~S}, 4 \mathrm{R}, 4 \mathrm{~S})$. Different letters in columns in the same day are significantly different $(\mathrm{P}<0.05)$ in Duncan's multiple range tests.

On day 21, the $\mathrm{pH}$ among all yogurt treatments ranged from 5.41 to 6.48 (Table 3). Yogurt that contained raspberry (1R), raspberry and $B$. lactis $(3 \mathrm{R})$, raspberry and both probiotics $(4 \mathrm{R})$ and strawberry and both probiotics $(4 \mathrm{~S})$ had a significantly lower $(\mathrm{P}<0.05) \mathrm{pH}$ compared to the control. The TTA\% among all yogurt treatments ranged from 0.40 to 0.60 (Table 4 ). In all yogurts containing raspberry (1R-4R) and strawberry $(1 \mathrm{~S}-4 \mathrm{~S})$, the lactic acid content was significantly higher $(\mathrm{P}<0.05)$ than the control.

On day 28 , the $\mathrm{pH}$ among all yogurt treatments ranged from 5.10 to 6.04 (Table 3). Yogurt containing raspberry $(1 \mathrm{R}-4 \mathrm{R})$ and strawberry $(1 \mathrm{~S}-4 \mathrm{~S})$ had a significantly lower $(\mathrm{P}<0.05) \mathrm{pH}$ compared to the control. The TTA\% among all yogurt treatments ranged from 0.36 to 0.60 (Table 4). All yogurt treatments containing berry had a significantly higher $(\mathrm{P}<0.05)$ lactic acid content compared to the control with the exception of yogurt containing raspberry (1R).

After 28 days of cold storage the $\mathrm{pH}$ in yogurts containing raspberry and strawberry were lower than control yogurts $(\mathrm{P}<0.05)$. The TTA\% in yogurts with raspberry and strawberry were higher than control yogurts which has no berry addition. Yogurts that contain berry possibly have a greater decrease in $\mathrm{pH}$ due to microorganisms that are more active in the presence of berries (Kailasapathy et al., 2000). The increase in TTA indicates that during the growth of bacteria there is lactic acid production (Agil \& Hosseinian, 2012).

\subsection{Antioxidant Activity}

\subsubsection{ORAC}

Raspberry had higher antioxidant activity $(\mathrm{P}<0.05)$ compared to strawberry with ORAC values of $505.72 \mu \mathrm{mol}$ $\mathrm{TE} / 100 \mathrm{~g}$ of fruit and $495 \mu \mathrm{mol} \mathrm{TE} / 100 \mathrm{~g}$ of fruit respectively (Table 5). In the study of Wang and Lin (2000), the antioxidant activity of fruits and leaves of different genotypes and development stages of blackberry, raspberry and strawberry fruits and was investigated. The ORAC values of fresh red and black raspberries from different cultivars ranged from 7.8 to $33.7 \mu \mathrm{mol}$ of TE/g during different stages of maturity (Wang \& Lin, 2000). The ORAC values of fresh strawberries from different cultivars ranged from 12.2 to $17.4 \mu \mathrm{mol}$ of TE/g during different stages of maturity (Wang \& Lin, 2000). The antioxidant capacity was lower in strawberry compared to blackberries and raspberries (Wang \& Lin, 2000). The higher the phenolic and flavonoid content, the higher the antioxidant activity of the fruit (Liu et al., 2002). 
Table 5. ORAC ${ }^{1}$ and TPC $^{2}$ values of raspberry and strawberry

\begin{tabular}{lll}
\hline Berry & ORAC $(\mu \mathrm{mol} \mathrm{TE} / 100 \mathrm{~g})$ & TPC $(\mathrm{GAE}(\mathrm{g} / \mathrm{kg})$ \\
\hline Raspberry & $505.05^{\mathrm{a}^{*}}$ & $0.20^{\mathrm{a}}$ \\
Strawberry & $495.42^{\mathrm{b}}$ & $0.18^{\mathrm{a}}$ \\
\hline
\end{tabular}

${ }^{1}$ ORAC $=$ Oxygen radical absorbance capacity values was calculated as $\mu$ mole Trolox Equivalent (TE)/100g of sample, ${ }^{2}$ TPC $=$ Total phenolic count of crude extract was calculated as g gallic acid equivalent (GAE)/kg of sample.* Different letters in columns are significantly different $(\mathrm{P}<0.05)$ in Duncan's multiple range tests.

\subsubsection{DPPH}

The DPPH scavenging capacity of raspberry was significantly $(\mathrm{P}<0.05)$ higher than strawberry with scavenging activity of $86.11 \%$ and $85.69 \%$ respectively (Figure 4). As shown in the Figure 4, it could be seen on the kinetic curve that the raspberry had a slightly higher scavenging activity during the first 20 minutes. Then, the rate of scavenging capacity of both raspberry and strawberry was almost even. The scavenging activity of six fruits was measured in a study by Li et al. (2009). The DPPH scavenging activity after 60 minutes were: chokecherry $(78.86 \%)$, raspberry $(51.23 \%)$, strawberry $(40.33 \%)$, Saskatoon berry $(36.59 \%)$, wild blueberry $(34.13 \%)$ and seabuckthorn (29.97\%) (Li et al., 2009). In a study by Ogawa et al. (2008), the anthocyanin composition and antioxidant activity of various berries were measured. After 30 minutes of incubation, the \% DPPH scavenging activity of raspberry and strawberry was $46 \%$ and $25 \%$ respectively (Ogawa et al., 2008). The antioxidant activity of berries is attributed to the different antioxidants that are present (Ogawa et al., 2008).Our findings was in the agreement with those mentioned studies.

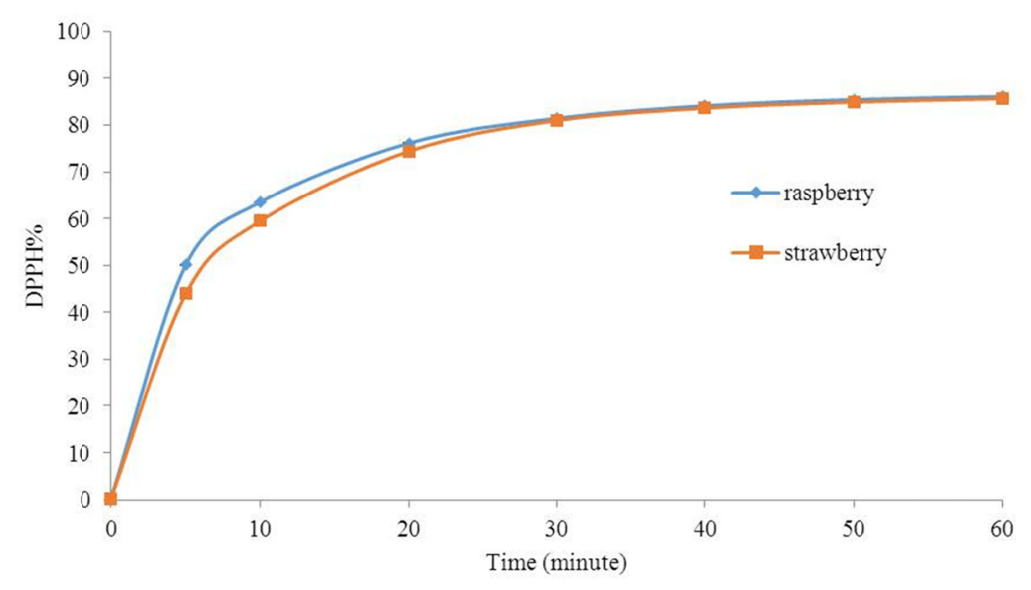

Figure 4. DPPH\% scavenging activity of raspberry and strawberry extracts

\subsubsection{TPC}

The TPC values of raspberry and strawberry were not significantly different $(\mathrm{P}<0.05)$ as shown in Table 5 . In a study by Wang et al. (2000), the TPC of red and black raspberries from different cultivars ranged from 0.57-3.40 g GAE/kg during different stages of maturity (Wang \& Lin, 2000). The TPC of fresh strawberries from different cultivars ranged from 0.95-1.50 g GAE/g during different stages of maturity (Wang \& Lin, 2000). Our findings were in agreement and in the parallel range of the mentioned study results. Moreover, in another study, the total phenolic and flavonoid contents in selected fruits and vegetables was investigated. In $0.1 \mathrm{~mL}$ of strawberry extract, the TPC was $0.36 \mathrm{~g}$ GAE/kg (Lin \& Tang, 2007).

\section{Conclusion}

In yogurt treatments containing L. acidophilus and raspberry, there was an increase in microbial counts for 21 consecutive days of cold storage. After 28 days of cold storage, the $\mathrm{pH}$ of all yogurt treatments containing berry and probiotics decreased and showed increased TTA\%. Raspberry had higher antioxidant activity than strawberry in both the ORAC and DPPH assay. This study shows that raspberries and strawberries have antioxidants activity and might act as a source of prebiotics. The presented results concerning the prebiotic effect 
of raspberry and strawberry are preliminary and further study is required to investigate how polysaccharides and other bioactive compounds extracted from raspberry and strawberry will affect the growth of starter and individual pure probiotic bacteria.

\section{Acknowledgments}

This project was supported by the Natural Sciences and Engineering Research Council of Canada (NSERC) and the Carleton University start-up funds. Authors thank to Dentz Orchards (Ottawa, Canada) for providing the fruit samples. This study is dedicated in the memory of Dr. Vahid Hosseinian.

\section{References}

Agil, R., \& Hosseinian, F. (2012). Dual Functionality of Triticle as a Novel Dietary Source of Prebiotics with Antioxidant Activity in Fermented Dairy Products. Plant Foods for Human Nutrition, 67, 88-93. http://dx.doi.org/10.1007/s11130-012-0276-2

Behrad, S., Yusof, M. Y., Goh, K. L., \& Baba, A. S. (2009). Manipulation of Probiotics Fermentation of Yogurt by Cinnamon and Licorice: Effects of Yogurt Formation and Inhibition of Helicobacter Pylori Growth in vivo. World Academy of Science, Engineering and Technology, 60, 520-524.

Collins, M. D., \& Gibson, G. R. (1999). Probiotics, prebiotics, and synbiotics: approaches for modulating the microbial ecology of the gut. The American Journal of Clinical Nutrition, 69(5), 1052S-1057S.

Del Rio, D., Rodriguez-Mateos, A., Spencer, J. P., Tognolini, M., Borges, G., \& Crozier, A. (2013). Dietary (poly)phenolics in human health: structures, bioavailability, and evidence of protective effects against chronic diseases. Antioxidants \& Redox Signaling, 18, 1818-1892. http://dx.doi.org/10.1089/ars.2012.4581

Espírito Santo, A. P., Cartolano, N. S., Silva, R. C., Soares, F. A. S. M., Gioielli, L. A., Perego, P., Oliveira, M. N. (2011). Fibers from fruit by-products enhance probiotic viability and fatty acid profile and increase CLA content in yogurts. International Journal of Food Microbiology, 154, 135-144. http://dx.doi.org/10.1016/j.ijfoodmicro.2011.12.025

Espírito Santo, A. P., Silva, R. C., Soares, F. A. S. M., Anjos, D., Gioielli, L. A., \& Oliveira, M. N. (2010). Açai pulp addition improves fatty acid profile and probiotic viability in yoghurt. International Dairy Journal, 20, 415-422. http://dx.doi.org/10.1016/j.idairyj.2010.01.002

Figueroa-Gonzzalez, I., Quijano, G., Ramirez, G., \& Cruz-Guerrero, A. (2010). Probiotics and prebiotics-perspectives and challenges. Journal of the Science of Food and Agriculture, 91(8), 1341-1348. http://dx.doi.org/10.1002/jsfa.4367

Gibson, G. R., \& Roberfroid, M. B. (1995). Dietary modulation of the human colonic microbiota: introducing the concept of prebiotics. Journal of Nutrition, 125(6), 1401-1412. http://dx.doi.org/10.1079/nrr200479

Gonçalves, M. M., Freitas, R., Nero, L. A., \& Carvalho, A. F. (2009). Enumeration of starter cultures during yogurt production using Petrifilm ${ }^{\mathrm{TM}}$ AC plates associated with acidified MRS and M17 broths. Journal of Dairy Research, 76, 229-233. http://dx.doi.org/10.1017/s0022029909003975

Hosseinian, F. S., Li, W., Hydamaka, A. W., Tsopmo, A., Lowry, L., Friel, J., \& Beta, T. (2007). Proanthocyanidin profile and ORAC values of manitoba berries, chokecherries, and seabuckthorn. Journal of Agricultural and Food Chemistry, 55(17), 6970-6976. http://dx.doi.org/10.1021/jf071163a

Huang, D., Ou, B., Hampsch-Woodill, M., Flanagan, J. A., \& Prior, R. L. (2002). High-throughput assay of oxygen radical absorbance capacity (ORAC) using a multichannel liquid handling system coupled with a microplate fluorescence reader in 96-well format. Journal of Agricultural and Food Chemistry, 50(16), 4437-4444. http://dx.doi.org/10.1021/jf0201529

Huebner, J., Wehling, R. L., \& Hutkins, R. W. (2007). Functional activity of commercial prebiotics International Dairy Journal, 17(7), 770-775. http://dx.doi.org/10.1016/j.idairyj.2006.10.006

Kailasapathy, K., \& Chin, J. (2000). Survival and therapeutic potential of probiotic organisms with reference to Lactobacillus acidophilus and Bifidobacterium spp. Immunology and Cell Biology, 78(1), 80-88. http://dx.doi.org/10.1046/j.1440-1711.2000.00886.x

Kailasapathy, K., Harmstorf, I., \& Phillips, M. (2008). Survival of Lactobacillus acidophilus and Bacterium animal ssp. lactis in stirred fruit yogurts. LWT- Food Science and Technology, 41, 1317-1322. http://dx.doi.org/10.1016/j.lwt.2007.08.009

Khurana, H. K., \& Kanawjia, S. K. (2007). Recent Trends in Development of Fermented Milks. Current 
Nutrition and Food Science, 3, 91-108. http://dx.doi.org/10.2174/1573401310703010091

Li, W., Hydamaka, A. W., Lowry, L., \& Beta, T. (2009). Comparison of antioxidant capacity and phenolic compounds of berries, chokecherry and seabuckthorn. Central European Journal of Biology 4, 499-506. http://dx.doi.org/10.2478/s11535-009-0041-1

Liazid, A., Palma, M., Brigui, J., \& Barroso, C. G. (2007). Investigation on phenolic compounds stability during microwave-assisted extraction. Journal of Chromatography A, 1140, 29-34. http://dx.doi.org/10.1016/j.chroma.2006.11.040

Lin, J. Y., \& Tang, C. Y. (2007). Determination of total phenolic and flavonoid contents in selected fruits and vegetables, as well as their stimulatory effects on mouse splenocyte proliferation. Food Chemistry, 101, 140-147. http://dx.doi.org/10.1016/j.foodchem.2006.01.014

Liu, M., Li, X. Q., Weber, C., Lee, C. Y., Brown, J., \& Liu, R. H. (2002). Antioxidant and antiproliferative activities of raspberries. Journal of Agricultural and Food Chemistry, 50(10), 2926-2930. http://dx.doi.org/10.1021/jf0111209

Ogawa, K., Sakakibara, H., Iwata, R., Ishii, T., Sato, T., Goda, T., \& Kumazawa, S. (2008). Anthocyanin Composition and Antioxidant Activity of the Crowberry (Empetrum nigrum) and Other Berries. Journal of Agricultural and Food Chemistry, 56, 4457-4462. http://dx.doi.org/10.1021/jf800406v

Ötles, S., Çagındı, Ö., \& Akçiçek, E. (2003). Probiotics and Health. Asian Pacific Journal of Cancer Prevention, 4, 369-372.

Talwalkar, A., \& Kailasapathy, K. (2004). A Review of Oxygen Toxicity in Probiotic Yogurts: Influence on the Survival of Probiotic Bacteria and Protective Techniques. Comprehensive Reviews in Food Science and Food Safety, 3, 117-124. http://dx.doi.org/10.1111/j.1541-4337.2004.tb00061.x

Vasiljevic, T., \& Shah, N. P. (2008). Probiotics-from metchnikoff to bioactives. International Dairy Journal, 18, 714-728. http://dx.doi.org/10.1016/j.idairyj.2008.03.004

Vinderola, C. G., \& Reinheimer, J. A. (1999). Culture media for the enumeration of Bifidobacterium bifidum and Lactobacillus acidophilus in the presence of yoghurt bacteria. International Dairy Journal, 9(8), 497-505. http://dx.doi.org/10.1016/s0958-6946(99)00120-x

Wang, S. Y., \& Lin, H. S. (2000). Antioxidant activity in fruits and leaves of blackberry, raspberry, and strawberry varies with cultivar and developmental stage. Journal of Agricultural and Food Chemistry, 48(2), 140-146. http://dx.doi.org/10.1021/jf9908345

Willett, W. C., Sacks, F., Trichopoulou, A., Drescher, G., Ferro-Luzzi, A., Helsing, E., \& Trichopoulos, D. (1995). Mediterranean diet pyramid: a cultural model for healthy eating. The American Journal of Clinical Nutrition, 61, S1402-1406.

\section{Copyrights}

Copyright for this article is retained by the author(s), with first publication rights granted to the journal.

This is an open-access article distributed under the terms and conditions of the Creative Commons Attribution license (http://creativecommons.org/licenses/by/3.0/). 